\title{
Proposed Bylaws of the American Political Science Association
}

\section{ARTICLE I. GENERAL 1. Name of Organization}

The name of the organization is the American Political Science Association ("the Association"). The Association is also known by its initials as APSA.

\section{Incorporation}

The American Political Science Association is organized as a nonprofit corporation under the laws of the District of Columbia.

\section{Statement of Purpose}

a. The purposes of the Association are to encourage the study of political science, support political scientists in their research, teaching, and public engagement, and publish materials related to political science.

b. In achieving these purposes, the Association strongly supports academic freedom, freedom of expression, and the equal protection of members and other political scientists regardless of country of origin or residence.

c. In pursuance of its purposes, the Association may not act in any way that is inconsistent with its tax-exempt status under section 501(c) (3) of the Internal Revenue Code.

$\mathrm{d}$. The Association as such is nonpartisan and does not support political parties or candidates. The Association encourages individual members in their research, publications, teaching, and public engagement to address significant political and social problems and policies, even when these problems and policies are controversial and subject to partisan discourse. As a corporate body, the Association may take positions on matters of public policy that directly affect its ability to function as an association and conduct business for the good of its members.

\section{Limitations}

a. No part of the net earnings of the Association may inure to the benefit of or be distributed to any director, employee or other individual, partnership, estate, trust or corporation having a personal or private interest in the Association. Compensation for services actually rendered and reimbursement for expenses actually incurred in attending to the affairs of the Association is limited to reasonable amounts. b. The Association will not carry on propaganda or otherwise attempt to influence legislation to an extent that would disqualify it for tax exemption under section 501(c) (3), and it will not participate in or intervene in (including the publishing or distributing of statements) any political campaign on behalf of or in opposition to any candidate for public office.

\section{Disposition of Assets}

In the event the American Political Science Association is dissolved, assets of the Association are to be applied and distributed as follows: All liabilities and obligations must be satisfied or adequate provision made to do so. Notice must be provided to the Attorney General of the District of Columbia prior to filing for dissolution as required by $\mathbb{S}$ 29-412.02(g) of the DC Code. Assets not held upon a condition or restriction requiring return, transfer, or conveyance to any other organization or individual are to be distributed by the Council, in trust or otherwise, to one or more charitable and educational organizations, organized under section 501 (c) (3) of the Internal Revenue Code, of a similar or like nature to the Association.

\section{ARTICLE II. MEMBERS}

The Council establishes all classes of membership and sets the associated dues.

\section{Individual Members}

a. Any person sharing the purposes of the Association may become a member upon payment of annual dues.

b. All members of Organized Sections or other sub-units of the Association must also be current members of the Association.

c. Privileges and rights of individual members. Individual members of the Association may:

1. elect the members of the Council;

2. attend and participate in the Annual

Business Meeting;

3. participate in the annual meeting and other conferences of the Association upon payment of additional registration fees;

4. petition to place questions before the membership for a vote;

5. call for a special meeting of the membership as provided in section 4 of this Article;
6. vote on amendments to these Bylaws;

7. inspect and copy the records of the Association as provided in the Policies Manual and in Article IV;

8. join one or more Organized Sections upon application and payment of the associated dues as set by those Sections; and

9. receive copies of Association journals upon payment of associated dues or other fees as set by the Council.

\section{Institutional Members}

a. The Council may create institutional categories of membership, set dues, and define privileges for those memberships.

b. Institutional members do not have voting rights.

\section{Regular Meetings of Members}

a. The Annual Business Meeting of the members will normally be held at the time of the annual meeting of the Association.

b. The purposes of the Annual Business Meeting of members are to hear reports from the Officers of the Association, and to propose, discuss and vote on matters of importance to the Association, which may include resolutions to be voted on by a ballot of the membership as provided in the Policies Manual.

(c). The annual business meeting may vote on resolutions to put before Council and membership as follows.

1. A quorum for voting at the annual business meeting is $1 \%$ of the membership as of the record date.

2. All resolutions to be put to a vote at the annual business meeting must be presented to the president and publicly announced no more than 60 days and no less than 21 days prior to the date of the meeting.

3. Provided a quorum has been achieved, a resolution to send to Council resolutions to be put before the membership, as described in Article III section 3 (c), is approved when a simple majority of those members at the annual business meeting has voted to approve.

4. If Council subsequently decides not to put the resolution before the membership for a vote, the immediately following annual business meeting may vote 
to send the same resolution directly to the membership. Provided a quorum of $2 \%$ of the membership as of the record date has been achieved, the resolution is approved when a simple majority of those members at the annual business meeting has voted to approve.

Notice of the time and place of the Annual Business Meeting will normally be given along with the announcement of the annual meeting of the Association during the preceding annual meeting. If circumstances prevent providing notice in this way or require a change in the time and place of a pending Annual Business Meeting, the Council will provide for notice to be transmitted to all members no more than 60 days and no less than 21 days prior to new date of the meeting.

\section{Special Meetings of Members}

a. Special meetings of the membership may be called by the Association President or a majority of the Council members at such time and place as the President or Council majority may determine, and must be called upon the written request of at least $10 \%$ of the membership as determined by the record date defined in Article IV.

b. Notice of all special meetings, stating the time and place of such meetings and the purposes for which the meeting is called, must be transmitted to all members no more than 60 days and no less than 21 days prior to the meeting date.

\section{Revocation of Membership}

The Council may revoke an individual's membership in the Association by a 2/3rds vote of all Council members after hearing from the member whose membership is in question. Unless earlier removed from office according to Article V, Section 9, the membership of a person serving as a member of the Council or an officer of the Association may not be revoked until the end of that person's term of office.

\section{ARTICLE III. VOTING AND PETITIONING}

\section{Policies Manual}

The Council adopts and amends the Policies Manual of the Association which is published on the Association's website and available in printed form to any member on request.

\section{Elections}

a. Election of officers and members of the Council is by electronic ballot as prescribed by these Bylaws and the Policies Manual. b. The quorum for elections of officers and members of the Council is $10 \%$ of the number of members as of the record date.

\section{Voting}

a. Members may vote by written (including electronic) ballot. When a matter is put before the members for a vote other than at a meeting, the ballot must state the number of ballots that must be returned to constitute a quorum, the proportion of affirmative votes required for approval, and the last date (no less than 30 days from the date the ballot is presented to the members) on which a ballot may be counted.

b. Voting on amendments to these Bylaws is by electronic ballot in accordance with the provisions of Article XIII and as prescribed in the Policies Manual.

c. Voting on resolutions on questions that are put before the membership is by electronic ballot and as prescribed in the Policies Manual. With respect to such resolutions:

1. The Council may initiate a resolution and present it to the membership for a vote.

2. If a minimum of $5 \%$ of the number of individual members deliver a petition to the President of the Association to put a matter to the membership for a vote, the Council must arrange for this vote to take place no less than 30 and no more than 90 days from the date the petition is received by the President.

3. Council may develop recommendations to be appended to the resolution before it is presented to the membership for a vote.

4. Within the limits of section 2, the Council may group resolutions or other matters requiring a vote of the membership to facilitate voting and the attainment of a quorum.

5. A quorum for a vote by written ballot is $10 \%$ or more of the number of individual members as of the record date.

6. Any such resolution is approved when the balloting period has closed provided a quorum has been achieved and a simple majority of those voting has voted to approve.

\section{ARTICLE IV. RECORD DATE; MEMBERSHIP ROSTER}

1. The Council may set a record date for the Annual Business Meeting and any other meeting or ballot of the members, which shall be no more than 70 days before the meeting or action requiring a determination of members. In the absence of action by the Council setting a record date, the record date for the
Annual Business Meeting shall be 70 days before the meeting, and the record date for a special meeting of the members called by the President shall be 30 days in advance of the meeting. For any meeting held or action taken by petition or written request of the members, as provided in these Bylaws, the record date shall be no more than 70 days before the date the petition or written request is submitted.

2. The list of members entitled to attend the Annual Business Meeting must be prepared as of the record date and must be available at the meeting for inspection by any member.

3. A member may ask to inspect the list of members by delivering a request to the Association's office at any time. The member must state in a request for inspection of the list a proper purpose for which inspection is requested. Within 10 business days after receiving such a request, the Association will deliver to the member either the list or an offer of a reasonable alternative method of achieving the identified purpose without providing access to or a copy of the list of members. Upon acceptance by the member, the Association will proceed to implementation of the proposed alternative.

\section{ARTICLE V. THE COUNCIL}

\section{Powers and Duties of the Council}

The Council is the governing body of the Association and directs the Association in its corporate capacity. It has charge and supervision of the Association's business, property and interests, including:

a. making policy including adopting, amending, and monitoring compliance with the Policies Manual;

b. approving the appointment and term of the Association's Executive Director;

c. adopting an annual budget and appropriating Association funds;

d. requesting and receiving reports annually or as appropriate in writing or in person from program chairs, editors of association journals, standing or other membership committees, and all other component units of the association;

e. making recommendations to the membership;

f. giving direction to officers;

g. creating and dissolving committees for stated periods and stipulated assignments, approving all committee appointments except those described in Article X section 3 , and giving direction to committees;

h. setting categories and dues for Association membership; 
i. approving the appointments and terms of the Association's journal editors;

j. approving and terminating Organized Sections; and

$\mathrm{k}$. keeping minutes of its meetings.

\section{Council Membership}

a. The Association's Council has 32 members: President-elect, President, PastPresident, 3 Vice Presidents, Treasurer, and 24 at-large members; the Executive Director is a non-voting ex-officio member of the Council.

b. Members of the Council must be members of the Association for the duration of their terms; any member of the Council whose membership lapses is considered to have resigned and the position becomes immediately vacant.

c. At-large members of the Council serve for a term of three years and may not serve consecutive terms. If an at-large member is elected as an officer, that member's position as an at-large member of Council becomes vacant and is filled by the Council as prescribed in section 6 of this Article. The term of the officer position determines the length of the term to be served by the newly-elected officer.

\section{Selection Process}

a. Nominees for Officers and at-large members of the Council are named by the Nominating Committee, or by petition of $5^{\circ}$ members on the record date delivered to the President at least 60 days prior to the date of voting as set in this section.

b. In selecting the nominees, the Nominating Committee shall make recommendations with due regard for geographic distribution, field of professional interest, methodological orientation, types of institutions where members are employed, race, ethnicity, gender and gender identity, sexuality, disability, and other important forms of diversity.

c. Individual members of the Association elect Council Members and Officers by electronic ballot as prescribed by Article III section 2 and in the Policies Manual.

d. The vote for Council Members and Officers takes place at the time announced on the Association's website.

e. The names of the nominees being proposed by the Nominating Committee and by members through petition will be announced to the membership as prescribed in the Policies Manual no less than 30 days before the vote takes place.

\section{Balloting}

a. For each position on the ballot, members may vote "for" (yes), "against" (no), or abstain.

b. In the event that a member votes "for" more candidates than can be elected to a position, the ballot is spoiled and not counted. A ballot returned with no votes for a position is counted as an abstention.

c. Candidates must receive more "for" votes than "against." In the event that there are more candidates than open positions, candidates receiving the largest number of positive votes will be deemed elected, followed by the candidate receiving the next largest number of positive votes, and so on, until all positions are filled.

\section{Term of Office}

Newly elected officers and members of the Council take office immediately following the conclusion of the Annual Business Meeting which follows the date of their election and serve for the term provided in these Bylaws and until a successor is selected as described in these Bylaws.

\section{Filling Interim Vacancies}

a. President. In the event that death, resignation, or inability to perform the duties of the office prevents the President from completing a term in office, the President-elect immediately succeeds to the office. Such succession leaves the office of President-elect vacant; it must be filled by the procedure described in the next section of this section.

b. President-elect. In the event that the President-elect succeeds to the office of President due to vacancy in the office of President, or in the event that death, resignation, or inability to perform the duties of the office prevents the President-elect from completing a term in office, the office must be filled by the procedure described in the this section.

1. If the vacancy occurs after the annual election has been completed as provided in Article III section 3, the term of the President-elect begins immediately and is extended to include the following year.

2. If the vacancy occurs before the annual election, the Nominating Committee nominates a candidate to serve as President-elect until the conclusion of the following Annual Business Meeting. The nominee assumes office upon an affirmative vote of the Council.

3. For the immediately following annual election, in addition to the selection of a President-Elect, a President shall be selected as provided for in these Bylaws. c. Members of the Council; other Officers. In the event that death, resignation, or inability to complete the term of any other officer or a member of the Council, the Council may, with the advice of the Nominating Committee, fill the vacancy for the balance of term which has become vacant.

d. Initial Terms Under These Bylaws. These Bylaws will go into effect at the start of the first Council election after they have been ratified. In preparation for the first election under these new Bylaws, the Nominating Committee shall select from among current Council members in their second year eight members to serve one additional year, from among current Council members in their first year eight to serve the remainder of the current term plus one additional year, and eight new members to serve three years. Officers elected under previous Bylaws and whose terms have not expired will continue to serve for the fulfillment of their terms.

\section{Council Meetings}

a. The Council must have at least two regular meetings each year, one to coincide with the Annual Meeting of the Association, and one or more on a schedule set by the Council during the meeting coinciding with the Annual Meeting. The President or the Executive Committee of the Association may call special meetings of Council with at least two weeks' notice of the time, place, and purpose of the special meeting.

b. 15 voting members constitute a quorum.

\section{Remote Meetings; Action without a Meeting}

A regular or special meeting of the Council does not need to be held at a geographic location if the meeting is held by means of the Internet or other electronic communications technology in a fashion which permits all members to hear (or participate by TTY or similar device) one another simultaneously. Any action required or permitted to be taken at a meeting of the Council may be taken without a meeting if all of the members of the Council consent in writing to the specific action and the written consents are included in the minutes or filed with the corporate records reflecting the actions taken. Action taken under this section is effective when the last Council member signs (including by electronic means) the consent, unless the consent specifies an earlier or later effective date. A consent signed under this section has the effect of a meeting vote and may be described as such in any document. 


\section{Removal from Office}

Any Council member may be removed on a vote of $2 / 3$ rds of the members of the Executive Committee and $75 \%$ of the Council; removal of a Council Member creates a vacancy which must be filled by the procedure described in section 6 of this Article.

\section{Conflict of Interest}

All Council members must annually sign and must comply with the conflict of interest statement that is included in the Policies Manual; a Council Member who fails to sign the conflict of interest statement by the date required is considered to have resigned and the position becomes immediately vacant.

\section{ARTICLE VI. OFFICERS}

The officers of the Association are the President, the President-Elect, the Past-President, and the Treasurer.

\section{Selection and Appointment}

The President-Elect is elected annually for a one-year term. The Treasurer is elected every third year for a three-year term. The form of the ballot is provided in Article $V$ section 4. Policies for the administration of the election are included in the Policies Manual.

The President-elect automatically succeeds to the office of President upon the completion of the President's term, or upon the occurrence of a vacancy as described in Article $\mathrm{V}$ section 6. The President automatically succeeds to the office of the Past-President upon the completion of the President's term.

\section{The President}

Powers and duties of the President: The President

a. presides at all meetings of the Council, the Executive Committee, and the Annual Business Meeting;

b. with the advice of the Council, prepares the agenda for the Annual Business Meeting; c. makes a report to the Annual Business Meeting;

d. sees to it that the business of the Association is faithfully transacted;

e. appoints Council members to the Policy Committees of Council and appoints the chairs of those committees;

f. proposes members of the Nominating Committee to the Council for appointment; g. serves in other capacities as requested by the Council; and

h. serves as a non-voting ex-officio member of all Policy committees.

\section{The President-Elect}

Powers and duties of the President-Elect. The President-Elect:

a. proposes for approval by the Council all members of Standing and Membership committees who will serve during the President-elect's term as President; and

b. appoints the program co-chairs for the Association's Annual Meeting and the Association's Teaching and Learning Conference.

\section{The Past-President}

The Past-President advises the President in the faithful performance of the office and represents the Association on such occasions as requested by the President. Presides as President pro tem in the event of a temporary absence of the President.

\section{The Treasurer}

Powers and duties of the Treasurer. The Treasurer:

a. reviews and approves the arrangements for the receipt, custody, and disbursement of Association funds, and for keeping the Association's accounts;

b. reports on the Association's financial condition to the Annual Business Meeting; and

c. oversees the performance of the Association's investment manager and advises the Council of the manager's recommendations on investment policy.

\section{Vice Presidents}

Three Vice Presidents serve one year terms and must be former members of Council.

\section{ARTICLE VII. EXECUTIVE DIRECTOR}

a. The Executive Director of the Association is selected by the Council and is a non-voting ex-officio member of Council.

b. Powers and duties of the Executive Director. The Executive Director:

1. serves as the chief executive officer of the Association and transacts its business;

2. has charge of the offices, employees, and agents of the Association;

3. formulates plans and policies for the accomplishment of the Association's purposes and, upon the approval of the Council, is responsible for administration of the Association's affairs;

4. has custody of the Association's funds, discharges its obligations, and maintains its accounts;

5. makes an annual report to the Council;

6. keeps minutes of the Council and Executive Committee meetings;
7. consults with the President as questions of policy arise; and

8. assists and advises all Committees in their work.

\section{ARTICLE VIII. COUNCIL COMMITTEES}

\section{Executive Committee}

The Council has an Executive Committee. a. Membership and Composition. The Executive Committee has nine members: the President, President-Elect, Past-president, Treasurer, and the Chairs of all the Policy Committees. The Executive Director also serves as a non-voting ex-officio member.

b. Duties. The Executive Committee:

1. proposes agendas for Council meetings;

2. presents budget proposals to the Council and advises the Council on the financial performance and health of the Association;

3. reviews policy proposals before their presentation to the Council and may make recommendations for action by the Council on proposed policies;

4. oversees progress after decisions have been made; and

5. takes and approves minutes of its meetings and reports on its activities to the Council,

c. Powers. The Committee may act on behalf of the Council in areas and on matters that the Council delegates to it from time to time. The Committee may create Executive Committee subcommittees.

d. Meetings.

1. The Executive Committee has at least four regular meetings per year, one at the time of the Annual Meeting and three or more other meetings at times set by the Executive Committee at its meeting at the time of the Annual Meeting.

2. The President may call a special meeting of the Executive Committee with at least one week notice specifying the time, place, and purpose of the meeting.

3. A regular or special meeting of the Executive Committee does not need to be held at a geographic location if the meeting is held by means of the Internet or other electronic communications technology in a fashion which permits the members to hear (or participate by TTY or similar device) one another simultaneously.

4. Any action required or permitted to be taken at a meeting of the Executive Committee may be taken without a meeting if all of the members of the Executive Committee consent in writing to the 
specific action and the written consents are included in the minutes or filed with the corporate records reflecting the actions taken. Action taken under this section is effective when the last member of the Executive Committee signs (including by electronic means) the consent, unless the consent specifies an earlier or later effective date. A consent signed under this section has the effect of a meeting vote and may be described as such in any document.

5. Six voting members of the Executive Committee constitute a quorum.

\section{Policy Committees}

a. The Policy Committees may include but are not limited to a Membership and Professional Development Committee, a Publications Committee, a Conferences and Meetings Committee, a Teaching and Learning Committee, and a Public Engagement Committee. The purposes of Policy Committees are to assist the Council in its governance and leadership of the Association. A list showing the membership of the current Policy Committees is available on the Association's website and is available to any member on request.

b. Each Policy Committee is composed of four or more Council members including a chair. The President appoints committee members and chair each year for one-year terms, which may be renewed, and end no later than the end of the member's term on Council.

c. A Policy Committee develops and recommends to the Council policies relating to its area of responsibility, and reviews and advises the Council on the implementation of related Council decisions.

d. Policy committees advise, consult with, and accept proposals from Membership and Standing committees of the association as instructed by the President and specified in the Policy Manual.

e. Policy committees meet at least once a year prior to the meeting of the Council at the time of the Annual Meeting. The chair of a policy committee must give at least 10 days notice of any meeting, including the matter or matters to be discussed, to its members and to the President.

$\mathrm{f}$. The quorum of a Policy Committee is no less than half the number of members.

ARTICLE IX. STANDING

COMMITTEES OF THE ASSOCIATION 1. Nominating Committee

The Nominating Committee consists of six members of the Association. a. Membership and selection. Within 30 days of the conclusion of each Annual Business Meeting, the President appoints, with the advice and consent of the Council and with due regard for geographic distribution, field of professional interest, methodological orientation, types of institutions where members are employed, race, ethnicity, gender and gender identity, sexuality, disability, and other important forms of diversity, three members to the Nominating Committee to serve for two-year terms and designates the chair to serve for the following year.

b. Powers and duties. The Committee nominates to the membership candidates for the positions of President-elect, three Vice Presidents, eight at-large Council members each year, and a Treasurer every three years, in accordance with the provisions of Article $\mathrm{V}$ section 3. The Association must publish the list of nominees for members to view 120 days prior to the date of voting.

c. When selecting the nominees, the Nominating Committee makes recommendations with due regard for geographic distribution, field of professional interest, methodological orientation, types of institutions where members are employed, race, ethnicity, gender and gender identity, sexuality, disability, and other important forms of diversity.

d. In the event a vacancy occurs among the Officers or the Members of the Council, the Committee nominates to the Council a person to fill the vacancy as provided in Article V section 6.

e. The quorum of the Nominating Committee is noless than half the number of members.

\section{Rules and Elections Committee}

The Rules and Elections Committee consists of seven members of the Association.

a. Membership and composition. Within 30 days of the conclusion of each Annual Business Meeting, the President-elect appoints three members of the Association for two-year terms to the Rules and Elections Committee, and a member of the Council to serve as Chair for the following year.

b. Powers and duties. The Rules and Elections Committee:

1. oversees the election of officers and members of the Council and the processing of petitions of members as provided in these Bylaws and in the Policies Manual;

2. supervises the counting of ballots and certifies the results to the President and the Executive Director;

3. reviews the Policies Manual and may recommend to the Council additions, deletions, and modifications;
4. reviews compliance with these Bylaws by the Association and may advise changes in practices or policies and may also from time to time make recommendations to the Council as provided in Article XIV for amendments which the Council may present to the membership.

c. The quorum of the Rules and Elections Committee is no less than half the number of members.

\section{Audit Committee}

The Audit Committee consists of six members of the Association.

a. Membership and Composition. Two members from among the members of Council, who are not on the Executive Committee, and one from among the individual members of the Association, with experience with audit and financial matters, are appointed by the President-elect each year for two year terms which may not be repeated. The Presidentelect also appoints from among the members of the Committee a chair to serve for the following year. Previous members of the Audit Committee may serve as non-voting ex officio members of the committee at the invitation of its chair.

b. Powers and duties. At least once every five years, the Audit Committee retains an auditor for the Association, within the budget specified by the Council, who serves until a successor is retained; the auditor thus selected may not have served as the Association's auditor within the previous ten years.

c. The Committee receives reports from the auditor on behalf of the Association and presents the audit to Council along with any recommendations for action.

d. The Audit Committee will establish and oversee a published whistle blower policy providing protections for officers, staff, agents, and vendors.

e. The quorum of the Audit Committee is no less than half the number of members.

\section{Committee on Organized Sections}

The Committee on Organized Sections has six members.

a. Membership and composition. Members serve two-year terms. The Presidentelect shall nominate three members each year and a member to serve as chair for the following year.

b. Powers and duties. The Committee on Organized Sections:

1. prepares, reviews, and updates the Organized Section Handbook for approval by the Council; 
2. recommends the creation or termination of Organized Sections for approval by Council;

3. monitors policies and activities of Organized Sections, in consultation with Sections, on behalf of Council; and

4. may formulate plans and policies on Organized Sections, in consultation with Sections and any interested members of the Association, for consideration by Council.

5. The quorum of the Committee on Organized Sections is no less than half the number of members.

\section{ARTICLE X. MEMBERSHIP COMMITTEES}

1. The purposes of Membership Committees are to ensure that the Association governs itself efficiently and in a fully inclusive way, to assist the Association to make positive changes in the profession, to further the advancement of under-represented groups in the discipline, to articulate the highest ethical standards for the discipline, and for other purposes as specified by the Council in a resolution for the creation of a membership committee. Membership committees will normally interact closely with one or more Policy Committees of the Council as appropriate.

2. The Membership Committees may include but are not limited to the Committee on the Status of Women in the Profession, the Committee on the Status of Blacks in the Profession, the Committee on the Status of Asian-Americans in the Profession, the Committee on the Status of Latinos y Latinas in the Profession, the Committee on the Status of Lesbians, Gays, Bisexuals and Transgenders (LGBT) in the Profession, and the Committee on Professional Ethics, Rights and Freedoms. The Council may create or discontinue a Membership Committee, with notice, at any meeting.

3. A list of the current Membership Committees and their members is available on the Association's website and is available in printed form to any member on request.

4. Membership and Composition. For each membership committee, there shall be six or more members from among the Association's membership. The Presidentelect shall nominate two or more members each year, for three years terms of office, and a chair to serve for the following year. For newly created committees, the Presidentelect shall nominate at least 6 members, and designate one, two, or three year terms so that approximately one-third of the positions shall be open each year thereafter.

5. Powers and duties. Membership committees may develop proposals for recommendation to Council on matters affecting their areas of concern and, when accepted, assist Council and staff in implementing those recommendations.

6. Other committees. Council has the discretion to create other committees for specified purposes, with notice, at any time. A full list of membership committees is published on the Association's website and available in printed form to any member on request.

\section{ARTICLE XI. ORGANIZED SECTIONS}

1. Council may create Organized Sections for the purpose of building community around areas of research in political science. A list of the current Sections is appended to these bylaws, published on the Association's website and available in printed form to any member on request.

2. Governance. Organized Sections are governed as follows:

a. Organized Sections serve as membership entities within the Association.

b. Sections are components of APSA as a whole, are bound by its bylaws and legal status, and accountable to the Council.

c. Organized Sections must maintain by-laws outlining policies for section administration, elections, and finances that are uniform and consistent with the Association's bylaws and policies. A current copy of such bylaws must be on file with the Association.

d. Council oversees the activities and proceedings of Organized Sections on behalf of the APSA membership.

\section{Membership. Organized Sections:}

a. may charge membership dues, which will be collected as part of the overall dues collection of the Association.

b. Members of Organized Sections must simultaneously be members of APSA.

\section{ARTICLE XII. ACTION IN AN EMERGENCY}

1. For purposes of this Article, an emergency exists if a quorum of the Council cannot readily be assembled because of some catastrophic event. A catastrophic event is a sudden natural or human-made situation where change and destruction has occurred that has limited normal functions in daily living including communications and travel.

2. In anticipation of and for the duration of an emergency, the Council may modify lines of succession to accommodate the incapacity of any officer, Council member, employee, or agent and take any actions that may be necessary to preserve the Association and protect its purposes.

3. During an emergency:

a. Notice of a meeting of the Executive Committee, Council, or any committee need be given only to those persons it is practicable to reach and may be given in any practicable manner; and

b. The required quorum need not be established at such meeting.

4. Corporate action taken in good faith during an emergency to further the ordinary affairs of the Association binds the Association and may not be used to impose liability on a director, officer, employee, or agent.

\section{ARTICLE XIII. AMENDMENTS TO THE BYLAWS}

1. Amendments to these Bylaws may be proposed by the Council or by a petition signed by $10 \%$ of the number of members of the Association as of the record date.

2. The Council must put all proposed amendments to the vote of the members as prescribed in Article III section 3 and the Policies Manual. The Council may make recommendations on a proposed amendment when it is presented to the membership.

3. A quorum for a membership vote on amending the Bylaws is $10 \%$ of the number of individual members of the Association as of the record date as defined in Article IV. A proposed amendment is adopted if approved by $2 / 3$ rds of those voting. An amendment shall take effect immediately upon ratification unless the text of the amendment provides otherwise.

\section{ARTICLE XIII. INDEMNIFICATION}

Any present or former director, officer, or committee member of the Association, or other such person or persons so designated by the discretion of Council or by the President, or the legal representative of such person, shall be indemnified by the Association against all reasonable costs, expenses, and counsel fees paid or incurred in connection with any threatened, pending, or completed civil action, arbitration, mediation, administrative proceeding, criminal prosecution, or investigatory action to which any such person or his/her legal representative, may be made a party by reason of being or having been such a director, officer, committee member, or having serving the Association, pursuant to and to the full extent permitted by D.C. Code Title 29, Chapter 4, Subchapter VI, Part E. 


\section{ARTICLE XIV. RATIFICATION OF}

BYLAWS

These Bylaws will supersede all past constitutions and bylaws on approval of all of the following: a) a majority of the Council, b) a majority of those members attending the next annual all-member Business Meeting, and c) a majority of the members (regardless of whether members have previously voted in the business meeting) voting in a mail ballot, and will take effect at the start of the first election following these steps. 